1 Station Biologique de Roscoff, UMR 1931 (CNRS and Laboratoire Goëmar), Place Georges Teissier 29682 Roscoff Cedex, Bretagne, France

2 Station Biologique de Roscoff, UPR 9042 CNRS Place Georges Teissier, 29680 Roscoff, Bretagne, France

\section{Zobellia galactanovorans gen. nov., sp. nov., a marine species of Flavobacteriaceae isolated from a red alga, and classification of [Cytophaga] uliginosa (ZoBell and Upham 1944) Reichenbach 1989 as Zobellia uliginosa gen. nov., comb. nov.}

\author{
Tristan Barbeyron, ${ }^{1}$ Stéphane L'Haridon, ${ }^{2}+$ Erwan Corre, ${ }^{2}$ \\ Bernard Kloareg ${ }^{1}$ and Philippe Potin ${ }^{1}$ \\ Author for correspondence: Tristan Barbeyron. Tel: +332982923 32. Fax: + 33298292324. \\ e-mail: barboun@sb-roscoff.fr
}

\begin{abstract}
A mesophilic, aerobic, non-flagellated, gliding bacterium, forming yellow colonies and designated Dsij', was isolated from a red alga on the sea-shore of Roscoff, Brittany, France. Dsij ${ }^{\top}$ was selected for its ability to actively degrade both agars and carrageenans. The Gram-negative cells occurred singly or in pairs as long rods. The temperature range for growth was $13-45^{\circ} \mathrm{C}$, with an optimum at $35^{\circ} \mathrm{C}$. The $\mathrm{pH}$ range for growth at $35^{\circ} \mathrm{C}$ was from 6.0 to 8.5, with an optimum around $\mathrm{pH} 7 \cdot 0$. The $\mathrm{NaCl}$ concentrations required for growth at $35{ }^{\circ} \mathrm{C}$ and $\mathrm{pH} 7.0$ ranged from 5 to $60 \mathrm{~g} \mathrm{I}^{-1}$, with an optimum around $25 \mathrm{~g} \mathrm{I}^{-1}$. The $\mathrm{G}+\mathrm{C}$ content of the genomic DNA was 42-43 mol\%. Phylogenetic analysis of $16 \mathrm{~S}$ rRNA gene sequences indicated that strain $\mathrm{Dsij}^{\mathrm{T}}$ is closely related to [Cytophaga] uliginosa DSM 2061'. Phenotypic features, however, allowed Dsij ${ }^{\top}$ and [Cytophaga] uliginosa strains to be distinguished on the basis of ten traits (spreading behaviour, assimilation of eight compounds and amylase production). Their total protein profiles were also different and DNA-DNA hybridization experiments confirmed that $D{ }^{\top}{ }^{\top}{ }^{\top}$ constitutes a new species, distinct from [Cytophaga] uliginosa. Based on the phenotypic features and the phylogenetic relationships of the Flavobacteriaceae, a new genus designated Zobellia gen. nov. is proposed to include Zobellia galactanovorans gen. nov., sp. nov., while [Cytophaga] uliginosa becomes Zobellia uliginosa comb. nov. The type strain of Zobellia galactanovorans is Dsij ${ }^{\top}\left(=\right.$ DSM $^{12802^{\top}}=\mathrm{CIP}^{\mathrm{T}}$ 106680').
\end{abstract}

Keywords: Zobellia galactanovorans, Zobellia uliginosa, [Cytophaga] uliginosa, Flavobacteriaceae, carrageenase and agarase activities

\section{INTRODUCTION}

Agars and carrageenans are cell wall galactans extracted from various marine red algae. They exhibit unique rheological properties and are widely used as

\footnotetext{
† Present address: Institut Universitaire Européen de la Mer, UMR 6539 CNRS-Université de Bretagne Occidentale,Technopôle Brest-Iroise, Place Nicolas Copernic, 29280 Plouzané, Bretagne, France.

The GenBank accession number for the $16 \mathrm{~S}$ rDNA sequence of strain Dsij ${ }^{\top}$ is AF208293.
}

texturing agents in various industries (De Ruiter \& Rudolph, 1997). They consist of a linear backbone of D-galactose residues linked by alternating $\alpha(1 \rightarrow 3)$ and $\beta(1 \rightarrow 4)$ linkages. In agars the $\alpha(1,4)$-linked galactose units are in the L configuration whereas they are in the D configuration in carrageenans. A further layer of complexity is the occurrence of a 3,6-anhydro bridge in the $\alpha(1,4)$-linked galactose residues and the number of ester-sulfate substituents per digalactose repeating unit, that vary from 0 in agarose to 3 in $\lambda$-carrageenan (Rees, 1969; Craigie, 1990). 
A bacterium that degrades microbiological agar was first discovered at the beginning of this century (Gran, 1902). Interestingly, as early as the 1940s, Humm (1946) discriminated between marine bacteria according to their specific hydrolytic activity on gel-forming extracts from seaweeds that were later distinguished as agarophytes and carrageenophytes when the structures of agars and carrageenans became known (Araki \& Arai, 1956, 1957; Rees, 1962). Since then, many agarolytic and carrageenolytic activities have been described from Bacteria as diverse as Flavobacterium (ZoBell \& Upham, 1944), Cytophaga (Duckworth \& Turvey, 1969; Sarwar et al., 1983; Potin et al., 1991), Pseudomonas (Weigl \& Yaphe, 1966; Hofsten \& Malmqvist, 1975; Vattuone et al., 1975; Greer \& Yaphe, 1984), Pseudoalteromonas and Alteromonas (Groleau \& Yaphe, 1977; Morrice et al., 1983; Leon et al., 1992; Potin et al., 1993), as well as Streptomyces (Bibb et al., 1987) and Vibrio (Aoki et al., 1990; Sugano et al., 1993).

Very little information, however, is available on the carrageenase activities of the Flavobacteriaceae and Cytophagaceae (Sarwar et al., 1983; Holmes et al., 1984; Reichenbach, 1989; Bernardet et al., 1996). The marine bacterium '[Cytophaga] drobachiensis' strain Dsij ${ }^{\mathrm{T}}$ (square brackets indicate a generically misnamed taxon and quotation marks indicate a name not yet validated), isolated from the red alga Delesseria sanguinea, was shown to possess the enzymic machinery to completely degrade various red algal galactans, including $\kappa$-carrageenase (Potin et al., 1991; Barbeyron et al., 1998), l-carrageenase (Potin et al., 1991, 1992; Barbeyron et al., 2000) and two different $\beta$-agarases (Potin, 1992). Humm (1946) had described the behaviour of a non-motile marine pseudomonad, 'Pseudomonas drobachiense' (Lundestad) Stanier (1941), on gels prepared from the red algal genera Chondrus, Agardhiella and Gracilaria, which contain $\kappa$-carrageenan, $l$-carrageenan and agar, respectively, as main cell wall polysaccharides. The morphological and biochemical features reported by Humm (1946) for ' $P$. drobachiense' are very similar to the characteristics of strain Dsij ${ }^{\mathrm{T}}$ (Potin, 1992). However, Potin (1992) showed that this latter strain behaves as a gliding bacterium. Based on the above results, on the definition of the genus Pseudomonas, which includes species motile by flagella, on the report of ' $P$. drobachiense' as incertae sedis (Doudoroff \& Palleroni, 1974) as well as on the evidence showing that strain Dsij ${ }^{\mathrm{T}}$ belongs to the Cytophaga-FlavobacteriumBacteroides (CFB) group, the name '[Cytophaga] drobachiensis' (Lundestad) was proposed for strain Dsij ${ }^{\mathrm{T}}$ in our reports on the cloning of its carrageenase genes (Barbeyron, 1993; Flament, 1999; Barbeyron et al., 1998).

Since the studies of Bernardet et al. (1996) and Nakagawa \& Yamasato (1993, 1996), the order Cytophagales, i.e., the rRNA superfamily V of the Bacteria or the CFB group (Bernardet et al., 1996), has been revisited. The family Flavobacteriaceae has been amended (Bernardet et al., 1996) and it now includes Flavobacterium, Capnocytophaga (Leadbetter et al., 1979) and Chryseobacterium as major genera (Vandamme et al., 1994). The type genus of the family, Flavobacterium, has also been amended (Bernardet et al., 1996). However, misnamed taxa such as those of the [Flexibacter] maritimus group, i.e. [Flexibacter] maritimus and [Flexibacter] ovolyticus (Bowman et al., 1998), as well as [Cytophaga] uliginosa, [Cytophaga] marinoflava, [Cytophaga] latercula and the Melosiracolonizing bacterium strain IC166 (Bowman et al., 1998), are classified in this family.

In the present work, we describe in detail the strain Dsij ${ }^{\mathrm{T}}$, so far known as '[Cytophaga] drobachiensis'. Several lines of evidence, based on the sequence of its 16S rDNA, DNA-DNA hybridizations, phylogenetic analyses and phenotypic features, indicate that this taxon is very closely related to [Cytophaga] uliginosa. It is thus proposed that these two species represent a novel taxon, referred to as Zobellia gen. nov. '[Cytophaga] drobachiensis' thus becomes Zobellia galactanovorans strain Dsij ${ }^{\mathrm{T}}$ gen. nov., sp. nov., while [Cytophaga] uliginosa is renamed Zobellia uliginosa comb. nov.

\section{METHODS}

Enrichment, isolation and growth conditions. '[Cytophaga] drobachiensis' strain Dsij ${ }^{\mathrm{T}}$ was isolated from the red alga Delesseria sanguinea (Huds.) Lamour. (Ceramiales, Rhodophyta) (Potin et al., 1991). Algae were collected in the English Channel near Roscoff (Brittany, France) and thallus fragments were deposited on a basal salts medium (Quatrano \& Caldwell, 1978), which contained 2\% (w/v) $l$-carrageenan. To obtain pure cultures with galactanolytic activities, subcultures of isolates were streaked on the same medium supplemented with $2 \% l$-carrageenan, $1.5 \%(\mathrm{w} / \mathrm{v})$ agar, $1 \% \kappa$-carrageenan or $1.2 \% \lambda$-carrageenan mixed with $1.5 \%$ agar. Isolated strains were grown in ZoBell medium 2216E (ZoBell, 1941), liquid or solidified with agar or carrageenan. When it was desirable to avoid attack of the substratum, strains were grown on ZoBell solidified with $0.7 \%$ (w/v) Phytagel (a gellan gum; Sigma). Stock cultures of isolate Dsij ${ }^{\mathrm{T}}$ were stored in the culture medium at $4{ }^{\circ} \mathrm{C}$. For long-term storage, pure cultures were stored at $-80^{\circ} \mathrm{C}$ in the same medium containing $20 \%$ (v/v) glycerol. [Cytophaga] uliginosa DSM $2061^{\mathrm{T}}$ was obtained from the Deutsche Sammlung von Mikroorganismen und Zellkulturen (DSMZ) collection, Braunschweig, Germany. All of the Cellulophaga species, namely Cellulophaga baltica (LMG 18535 ${ }^{\mathrm{T}}$ ), Cellulophaga fucicola (LMG 18536 ${ }^{\mathrm{T}}$ ) and Cellulophaga lytica (ATCC $23178^{\mathrm{T}}$ ), were generously provided by Dr J.-F. Bernardet. These marine bacteria were grown in ZoBell medium.

Determination of growth conditions. Growth was monitored by measuring the increase in optical density at $600 \mathrm{~nm}$ using a Spectronic 20D spectrophotometer (Bioblock). All growth experiments were performed in duplicate. The optimal $\mathrm{pH}$ value was determined in the Cytophaga marine medium described by DSMZ, composed of $\left(1^{-1}\right) 1 \mathrm{~g}$ tryptone, $1 \mathrm{~g}$ yeast extract, $0.7 \mathrm{~g} \mathrm{KCl}, 6.3 \mathrm{~g} \quad \mathrm{MgSO}_{4} .7 \mathrm{H}_{2} \mathrm{O}, \quad 4.6 \mathrm{~g}$ $\mathrm{MgCl}_{2} \cdot 6 \mathrm{H}_{2} \mathrm{O}, 1.2 \mathrm{~g} \mathrm{CaCl}_{2} .2 \mathrm{H}_{2} \mathrm{O}$, and using $10 \mathrm{mM}$ MES for $\mathrm{pH} 5 \cdot 0,5 \cdot 5$ and $6 \cdot 0,10 \mathrm{mM}$ PIPES buffer for $\mathrm{pH} 6 \cdot 5$ and $7 \cdot 0$, 
$10 \mathrm{mM}$ HEPES buffer for $\mathrm{pH} 7 \cdot 5,10 \mathrm{mM}$ Tris/ $\mathrm{HCl}$ for $\mathrm{pH} 8.0$ and 8.5 , and no buffer for $\mathrm{pH} 9 \cdot 0$. The effect of $\mathrm{NaCl}$ on growth was determined in the same medium containing 0 , $1,2,3,4,5,6,7$ or $8 \%(\mathrm{w} / \mathrm{v}) \mathrm{NaCl}$. The temperature range for growth was determined between 10 and $50{ }^{\circ} \mathrm{C}$. The effects of $\mathrm{pH}$ and $\mathrm{NaCl}$ concentration were determined at $30{ }^{\circ} \mathrm{C}$.

Phenotypic characterization. Morphological features were investigated with cells in exponential phase and grown in Cytophaga marine medium. Gliding motility was tested with colonies on Phytagel, mounted between a slide and a cover glass, by phase-contrast microscopic observation of the living cells present at the edges of the colony. To determinate the respiratory type, bacteria were inoculated into Veillon tubes containing ZoBell medium solidified with $0.6 \%$ agar. Oxygen was removed from the medium by boiling. To determine their oxidative or fermentative behaviour, bacteria were inoculated into a modified Leifson $\mathrm{O}-\mathrm{F}$ medium (Hugh \& Leifson, 1953; Smibert \& Krieg, 1981), containing $0.5 \%(\mathrm{w} / \mathrm{v})$ glucose. Oxidase activity was assayed with disks impregnated with dimethyl- $p$-phenylenediamine oxalate (Diagnostics Pasteur). Catalase activity was assayed by mixing one colony from a ZoBell agar plate with a drop of hydrogen peroxide $(10 \%, \mathrm{v} / \mathrm{v})$ The ability to use simple carbohydrates as carbon sources was tested in Basal Salt Medium (Quatrano \& Caldwell, 1978), containing the carbohydrate under investigation at a concentration of $0.5 \%$ $(\mathrm{w} / \mathrm{v})$. The strain was assayed for amylase activity using starch at a concentration of $0.2 \%(\mathrm{w} / \mathrm{v})$ in ZoBell agar or in ZoBell Phytagel plates. DNase activity was detected in DNA agar (Diagnostics Pasteur), supplemented with $25 \mathrm{~g} \mathrm{NaCl}$ $1^{-1}$. Amylase and DNase activities were revealed with a lugol solution on starch agar and with $1 \mathrm{M} \mathrm{HCl}$ on DNase agar, respectively. Cellulolytic activities were tested using strips of Whatman no. 1 or no. $3 \mathrm{MM}$ Chr filter paper, on solid medium, as described by Dungan et al. (1989), and in liquid medium, either in the presence or in the absence of carbon sources, according to Smibert \& Krieg (1981). Paper strips were sterilized by UV irradiation and placed in the tubes so that a portion of the strips extended above the level of the medium. Plates and tubes were incubated at $25^{\circ} \mathrm{C}$ for 1 month. Liquefaction of CM-cellulose was tested after incubation of a dense inoculum in tubes filled with ZoBell medium supplemented with $3 \%(\mathrm{w} / \mathrm{v}) \mathrm{CM}$-cellulose for $15 \mathrm{~d}$ at $25^{\circ} \mathrm{C}$. Chitinolytic activity was tested as described by Dungan et al. (1989). Agarase, $\kappa$-carrageenase and $l$ carrageenase activities were tested both by a reducing sugar assay (Kidby \& Davidson, 1973) and by testing for degradation of a ZoBell medium solidified with $15 \mathrm{~g}$ agar $1^{-1}, 10 \mathrm{~g}$ $\kappa$-carrageenan $1^{-1}$ or $20 \mathrm{~g} l$-carrageenan $1^{-1}$. Strains which made a hole in the substratum were considered as positive. Production of flexirubin was assessed by flooding a $4 \mathrm{~d}$ plate culture with $20 \%(\mathrm{w} / \mathrm{v})$ potassium hydroxide followed by the observation of changes in colony colour from yellow to red or brown (Reichenbach et al., 1974). Other tests were performed by utilization of API $20 \mathrm{NE}$, API $50 \mathrm{CH}$ and API ZYM strips (BioMérieux) and by utilization of BIOLOG GN microplates. For these tests, the suspending medium was adjusted to a $\mathrm{NaCl}$ concentration of $25 \mathrm{~g} \mathrm{l}^{-1}$ and the preparations were incubated at $30^{\circ} \mathrm{C}$ for 1 week.

Antibiotic susceptibility. Sensitivity to chloramphenicol $\left(10 \mu \mathrm{g} \mathrm{ml}^{-1}\right)$, penicillin $\mathrm{G}\left(200 \mu \mathrm{g} \mathrm{ml}^{-1}\right)$, streptomycin $\left(200 \mu \mathrm{g} \mathrm{ml}^{-1}\right), \quad$ kanamycin $\quad\left(200 \mu \mathrm{g} \mathrm{ml}^{-1}\right)$, ampicillin $\left(200 \mu \mathrm{g} \mathrm{ml}^{-1}\right)$, rifampicin $\left(10 \mu \mathrm{g} \mathrm{ml}^{-1}\right)$ and tetracycline $\left(10 \mu \mathrm{g} \mathrm{ml}^{-1}\right.$ ) (all from Sigma) was tested at $30^{\circ} \mathrm{C}$.

Light and electron microscopy. An Olympus $\mathrm{BH} 2$ microscope equiped with an Olympus OM-2 camera was used to observe the bacteria and to obtain photomicrographs. Gram staining was carried out as described by Conn et al. (1957). For negative staining, $20 \mu \mathrm{l}$ of a bacterial suspension fixed with $2 \%(\mathrm{w} / \mathrm{v})$ glutaraldehyde was dropped onto Formvar/ carbon-coated grids (400 mesh) and stained with $4 \%(\mathrm{w} / \mathrm{v})$ uranyl acetate. Micrographs were taken on a model CM100 electron microscope (Philips) with an acceleration voltage of $80 \mathrm{kV}$.

Isolation of DNA. Genomic DNAs were obtained by using the procedure described by Barbeyron et al. (1984). The DNA was purified on a caesium chloride gradient and purity was checked spectrophotometrically.

DNA base composition. The Chargaff's coefficient of the DNA, expressed as the molar percentage of guanine plus cytosine $(\mathrm{mol} \% \mathrm{G}+\mathrm{C})$, was determined by the spectroscopic method of Ulitzur (1972) using Escherichia coli DNA as a standard, and also by measuring the melting points (Marmur \& Doty, 1962), using a Kontron spectrophotometer model Uvikon 940 equipped with a system disk 9009 (Kontron Instruments). The spectrophotometer was equipped with a Huber cryothermostat (Ministat HS40), which was regulated by a Huber temperature programmer (model PD415; Bioblock). Standard DNAs from E. coli $(50 \mathrm{~mol} \% \mathrm{G}+\mathrm{C})$, Clostridium perfringens $(26.5 \mathrm{~mol} \%$ $\mathrm{G}+\mathrm{C})$ and Micrococcus luteus $(72 \mathrm{~mol} \% \mathrm{G}+\mathrm{C})$, were purchased from Sigma.

Small subunit rDNA sequencing. $16 \mathrm{~S}$ rDNA was amplified by PCR with Taq polymerase (Promega), using the genomic DNA from strain Dsij ${ }^{\mathrm{T}}$ as template and two primers specific for Bacteria [8F primer: AGAGTTTGATCCTGGCTCAG (Hicks et al., 1992) and 1492R primer: GGTTACCTTGTTACGACTT (Kane et al., 1993)]. PCR reactions were typically carried out in a volume of $50 \mu \mathrm{l}$ containing $50-100 \mathrm{ng}$ template, $100 \mathrm{ng}$ of each of the two specific primers, $250 \mu \mathrm{M}$ of each dNTP, $1.5 \mathrm{mM} \mathrm{MgCl}, 1 \times$ buffer (Promega) and 2.5 U polymerase. The different steps of PCR were as follows: $5 \mathrm{~min}$ at $95^{\circ} \mathrm{C}$; then 25 cycles of $1.5 \mathrm{~min}$ at $95^{\circ} \mathrm{C}, 1.5 \mathrm{~min}$ at $53{ }^{\circ} \mathrm{C}$ and $2.5 \mathrm{~min}$ at $72^{\circ} \mathrm{C}$; then finally a polymerization step of $8 \mathrm{~min}$ at $72^{\circ} \mathrm{C}$. PCR products were cloned in vector pCRII2.1 and sequenced, using Texas-red labelled primers, a Thermosequenase kit (RPN 2444; Amersham) and a Vistra 725 automated sequencer.

Phylogenetic analysis of the rDNA gene sequence of strain Dsij $^{\top}$. 16S rDNA sequences were aligned manually with a representative set of $16 \mathrm{~S}$ rRNA sequences obtained from the Ribosomal Database Project (Maidak et al., 1999) and from recent GenBank releases (Benson et al., 1999). The secondary structure was used as a guide to ensure that only homologous regions were compared. Of the 1483 nucleotides that were sequenced, 1257 were used in the phylogenetic analysis. Distance matrix, maximum-parsimony (Fitch, 1971) and maximum-likelihood (Felsenstein, 1981) methods were applied, as implemented in the ARB software package (Ludwig \& Strunk, 1997). The neighbour-joining method (Saitou \& Nei, 1987) was performed with the Jukes and Cantor distance correction (Jukes \& Cantor, 1969) and bootstrap analysis was used to provide confidence estimates for the phylogenetic tree topologies (Felsenstein, 1985).

DNA-DNA hybridization. Genetic relatedness was investigated by slot-blot DNA-DNA hybridization, using the ECF random-prime labelling and signal amplification system (ECF kit RPN 5752; Amersham) and following the procedure described by Kristjánsson et al. (1994). Increasing amounts of target DNA $(25,50$ and $100 \mathrm{ng})$, denatured in 
0.4 M NaOH, were slotted onto a nylon hybridization membrane (Bio-Rad) and probed with $200 \mathrm{ng}$ fluoresceinlabelled tracer DNA. For each duplicate of DNA-DNA association, the hybridization temperature was chosen in the optimal range in the hybridization buffer (Johnson, 1984; Ivanova et al., 1988). For example, for a $\mathrm{G}+\mathrm{C}$ content of $43 \mathrm{~mol} \%$, DNA-DNA associations were carried out for $15 \mathrm{~h}$ at $60{ }^{\circ} \mathrm{C}$ in buffer consisting of $4 \times \mathrm{SSC}$ supplemented with $19 \%$ formamide, $0.5 \%$ blocking agent, $5 \%$ dextran sulphate and $100 \mu \mathrm{g}$ denatured sheared salmon sperm DNA ml ${ }^{-1}$. Final high-stringency washes and signal amplification were performed according to the manufacturer's instructions. Hybridization signals were detected with a Storm 640 fluorescence scanner (Molecular Dynamics) and analysed with the IMAGE-QUANT program. The signal (maximum peak area) produced by hybridization of the probe with homologous target DNA was set at 100\% and compared with the signal generated by heterologous DNA. DNA-DNA hybridization was also monitored by spectrophotometry (Huss et al., 1983), using the same equipment as for analysing the DNA base composition. The renaturation rates were calculated using the Kontron program and the degree of annealing was estimated according to the formula of De Ley et al. (1970).

Fatty acid analysis. Fatty acid composition of cells grown on either Cytophaga marine agar or GYM $\left(1^{-1}: 4 \mathrm{~g}\right.$ glucose, $4 \mathrm{~g}$ yeast extract and $10 \mathrm{~g}$ malt extract) was determined by the DSMZ.

Cellular protein extraction and SDS-PAGE. Cell pellets were washed twice with artificial sea water, suspended in $0.5 \mathrm{mM}$ Tris $/ \mathrm{HCl}$ buffer $(\mathrm{pH} 8.0$ ) containing $2 \mathrm{mM}$ DTT, $1 \mathrm{mM}$ EGTA, $1 \mathrm{mM}$ EDTA and $0.4 \mathrm{mM}$ PMSF, and disrupted by sonication on ice ( 6 pulses of $10 \mathrm{~s}$ at $60 \mathrm{~W})$. After two runs of centrifugation at $15000 \mathrm{~g}$ and $4{ }^{\circ} \mathrm{C}$ for $20 \mathrm{~min}$, proteins were electrophoresed on a SDS-PAGE gel. Protein concentrations were estimated by the Bradford method, using a Bio-Rad assay kit. Proteins were loaded onto $12 \%(\mathrm{w} / \mathrm{v})$ polyacrylamide gels (4\% stacking gels) along with the following molecular mass standards: rabbit skeletal muscle myosin $(200 \mathrm{kDa}), E$. coli $\beta$-galactosidase $(116.25 \mathrm{kDa})$, rabbit muscle phosphorylase B $(97 \cdot 40 \mathrm{kDa})$, bovine serum albumin $(66.20 \mathrm{kDa})$ and hen egg white ovalbumin $(45 \mathrm{kDa})$. Gels were stained with Coomassie Brillant Blue R250.

\section{RESULTS}

\section{Enrichment and isolation}

After 1 week of incubation of pieces of the red alga Delesseria sanguinea (Huds.) Lamour. at $20{ }^{\circ} \mathrm{C}$ on a basal salt medium supplemented with $2 \% \quad l$ carrageenan, 14 bacterial strains were isolated. On the basis of their capability to form holes in the substratum, 7 isolates displayed agarolytic activity only and 4 isolates possessed both agarolytic and carrageenolytic activities. These latter 4 strains were pigmented yellow or orange. Based on assays for carrageenase and agarase activities (Kidby \& Davidson, 1973), the isolate $\mathrm{Dsij}{ }^{\mathrm{T}}$ was the most active. In the presence of $0.25 \%$ non-purified $\lambda$-carrageenan, $\kappa$ - and $l$-carrageenase activities were maximal $(22$ and $8 \mathrm{U} \mathrm{ml}^{-1}$, respectively, at the end of the exponential phase at $20^{\circ} \mathrm{C}$; Potin et al., 1991). The isolate Dsij ${ }^{\mathrm{T}}$ was therefore studied in more detail.

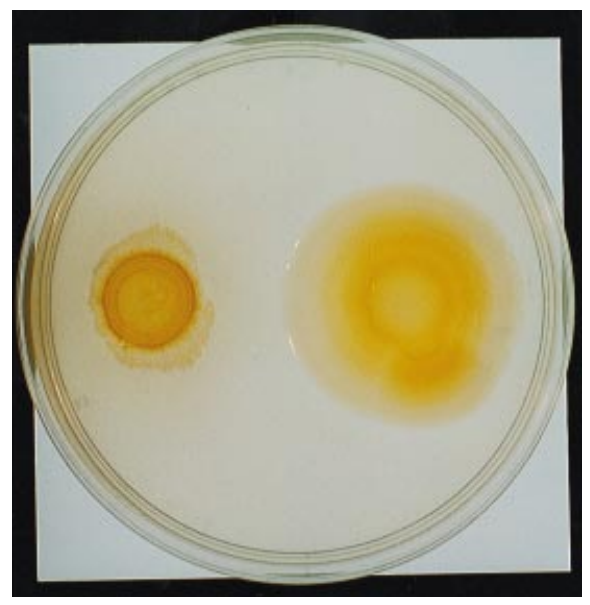

Fig. 1. ZoBell agar plate with a colony of [Cytophaga] uliginosa (on the left) and strain $\mathrm{Dsij}^{\mathrm{T}}$ (on the right). Plates were incubated at $22^{\circ} \mathrm{C}$ for $5 \mathrm{~d}$. Note the differences in colour and spreading behaviour.

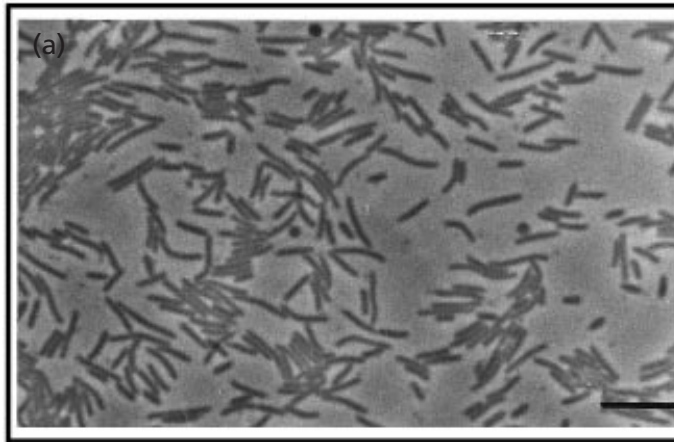

(b)

Fig. 2. Phase-contrast micrograph (a) and electron micrograph (b) of strain Dsij ${ }^{\top}$. No flagella were observed on the negatively stained cells. Bars: (a) $10 \mu \mathrm{m}$; (b) $1 \mu \mathrm{m}$.

\section{Colonial and cellular morphology}

The strain Dsij ${ }^{T}$ exhibited spreading growth on agar plates, forming yellow-orange colonies of $1 \mathrm{~mm}$ diameter within $3 \mathrm{~d}$ at $20^{\circ} \mathrm{C}$. After 1 week of culture, the agar plate was degraded under and near the edges of the colonies. When a culture drop of the strain Dsij ${ }^{\mathrm{T}}$ in exponential phase was inoculated at the centre of a Petri dish, the colony expanded concentrically (Fig. 1), 
degrading agar within $24 \mathrm{~h}, \kappa$-carrageenan within $48 \mathrm{~h}$ and liquefying $l$-carrageenan within $24 \mathrm{~h}$. In comparison, carrageenase activities from [Cytophaga] uliginosa were lower, even though the agarase activities of the two strains were similar. [Cytophaga] uliginosa colonies were orange and spread at a slower rate (Fig. 1). Observations of colonies on Phytagel plates by phase-contrast microscopy indicated that both strains had a gliding motility. Strain Dsij ${ }^{\mathrm{T}}$ was very active and cells glided towards the outside of the colony at about $1 \mu \mathrm{m} \mathrm{s}^{-1}$. In comparason, [Cytophaga] uliginosa cells moved very slowly and they did not seem to leave the colony. Strain Dsij ${ }^{\mathrm{T}}$ cells appeared as round-ended rods, about $0 \cdot 3-0 \cdot 4 \mu \mathrm{m}$ wide and 3.0-8.0 $\mu \mathrm{m}$ long (Fig. 2a) and they displayed Gram-negative staining. They occurred singly or in pairs. Under the microscope, the wet mount showed non-motile cells. Non-refractile spherical bodies appeared in stationary-phase cultures. No flagella were seen by electron microscopy (Fig. 2b).

\section{Determination of growth parameters}

Strain Dsij ${ }^{\mathrm{T}}$ grew between 13 and $45^{\circ} \mathrm{C}$, with an optimum around $35^{\circ} \mathrm{C}$, while no growth was detected at 10 or $46^{\circ} \mathrm{C}$ after 15 and $3 \mathrm{~d}$ of incubation, respectively (Fig. 3a). In contrast, [Cytophaga] uliginosa could not grow above $42{ }^{\circ} \mathrm{C}$. Growth was observed at $\mathrm{NaCl}$ concentrations ranging from 5 to $60 \mathrm{~g} \mathrm{l}^{-1}$ (Fig. 3b), with an optimum around $25 \mathrm{~g} \mathrm{l}^{-1}$ (growth in the absence of salt was observed but not after five subcultures). No growth was observed at $\mathrm{NaCl}$ concentrations of $70 \mathrm{~g} \mathrm{l}^{-1}$ after $3 \mathrm{~d}$ of incubation at $30^{\circ} \mathrm{C}$. Growth was observed between $\mathrm{pH} 6.0$ and $8 \cdot 5$, with an optimum around $\mathrm{pH} 7 \cdot 0$ (Fig. $3 \mathrm{c}$ ). No growth was detected at pH 5.5 or 9.0 after $3 \mathrm{~d}$ of incubation at $30^{\circ} \mathrm{C}$. Under the optimal growth conditions $\left(35^{\circ} \mathrm{C}, \mathrm{pH} 7 \cdot 0\right.$ and $\left.25 \mathrm{~g} \mathrm{NaCl} 1^{-1}\right)$, the doubling time of strain $\mathrm{Dsij}^{\mathrm{T}}$ was around $50 \mathrm{~min}$.

\section{Determination of growth requirements}

Strain $\mathrm{Dsij}^{\mathrm{T}}$ was shown to be a strictly aerobic, seawater-requiring, chemo-organotrophic and heterotrophic organism, with an oxidative metabolism that used oxygen as the electron acceptor. Nitrate could also be used as electron acceptor. The biochemical characteristics of strain Dsij ${ }^{\mathrm{T}}$, as compared to those of [Cytophaga] uliginosa strain DSM 2061 ${ }^{\mathrm{T}}$, are reported in Table 1. Strain Dsij ${ }^{\mathrm{T}}$ synthesized flexirubin and was able to degrade several polysaccharidic or proteic substrates, such as agar, $\kappa$ - and $l$-carrageenan, starch and gelatin. It did not display any chitinolytic activity or cellulolytic activity, either against solid (paper) or amorphous (CM-cellulose) cellulose.

\section{Sensitivity to antibiotics}

The growth of strain Dsij ${ }^{\mathrm{T}}$ was inhibited by a concentration of $10 \mu \mathrm{g}$ rifampicin $\mathrm{ml}^{-1}$, and by $25 \mu \mathrm{g}$ chloramphenicol or tetracycline $\mathrm{ml}^{-1}$. No inhibition was observed with streptomycin, kanamycin, penicillin
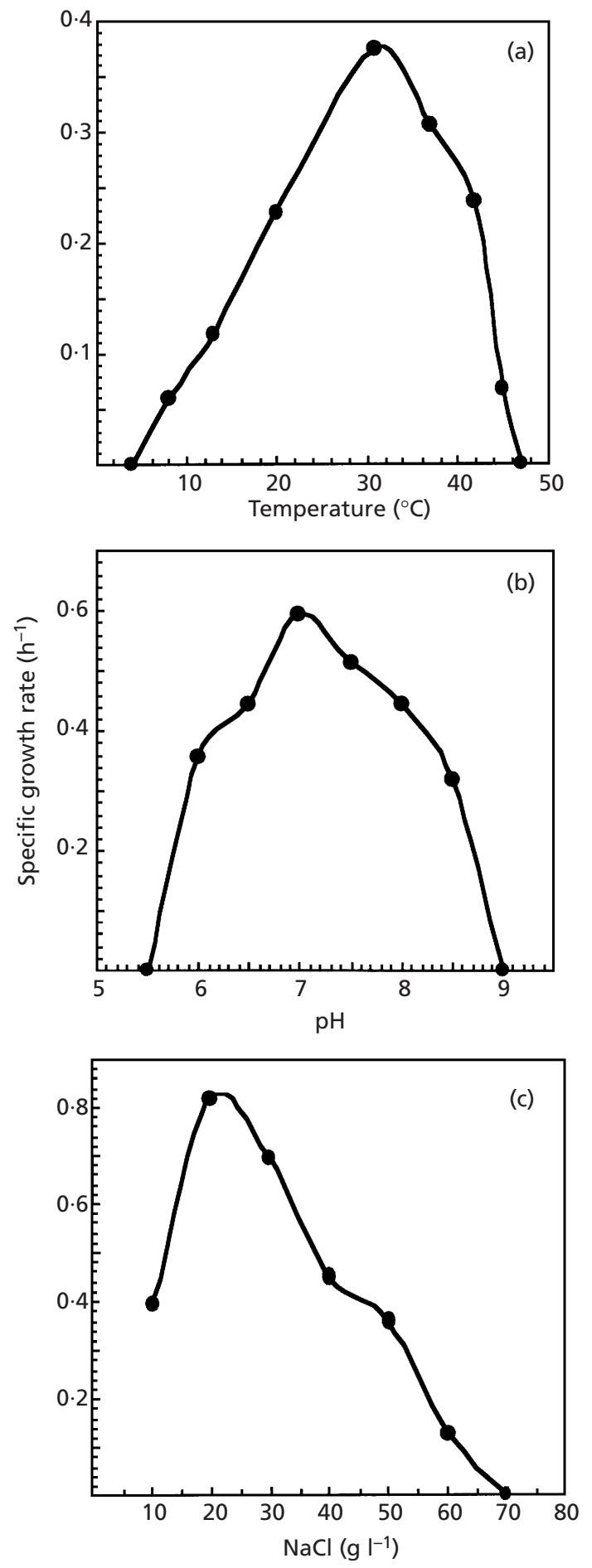

Fig. 3. Effect of temperature, $\mathrm{pH}$ and $\mathrm{NaCl}$ concentration on growth of isolate $\mathrm{Dsij}^{\mathrm{T}}$ in the Cytophaga marine medium described in Methods. Specific growth rates $(\mu)$ are plotted as a function of temperature in the presence of $25 \mathrm{~g} \mathrm{NaCl} \mathrm{I}^{-1}$ at $\mathrm{pH} 7.0(\mathrm{a})$, of the $\mathrm{pH}$ of the medium in the presence of $25 \mathrm{~g}$ $\mathrm{NaCl}{ }^{-1}$ at $35^{\circ} \mathrm{C}(\mathrm{b})$, and of $\mathrm{NaCl}$ concentration at $35^{\circ} \mathrm{C}$ and at $\mathrm{pH} 7$ (c).

G or penicillin A (ampicillin) at $200 \mu \mathrm{g} \mathrm{ml}^{-1}$. The same results were obtained with [Cytophaga] uliginosa strain DSM $2061^{\mathrm{T}}$. 
Table 1. Differential characteristics between strain Dsij ${ }^{\top}$ and [Cytophaga] uliginosa DSM $2061^{\top}$

Determined with API 20 NE strips (identification of non-enteric Gram-negative rods), API 50 $\mathrm{CH}$ strips (carbohydrate assimilation and acidification), API ZYM strips (enzymic activities), and BIOLOG GN microplates (carbon substrate assimilation).

\begin{tabular}{|c|c|c|c|}
\hline Strip & Substrate, reaction or enzyme & Dsij $^{\mathrm{T}}$ & $\begin{array}{c}{[\text { Cytophaga] }} \\
\text { uliginosa DSM 2061 }\end{array}$ \\
\hline API $20 \mathrm{NE}$ & $\begin{array}{l}\text { Reduction of nitrate to nitrite } \\
\text { Indole production } \\
\text { Glucose fermentation } \\
\text { Arginine dihydrolase } \\
\text { Urea } \\
\text { Aesculin hydrolysis } \\
\text { Gelatin hydrolysis } \\
\beta \text {-Galactosidase (PNPG*) } \\
\text { Arabinose assimilation } \\
\text { Gluconate assimilation }\end{array}$ & $\begin{array}{l}+ \\
- \\
- \\
- \\
- \\
+ \\
+ \\
+ \\
\pm \\
-\end{array}$ & $\begin{array}{l}+ \\
- \\
- \\
- \\
- \\
+ \\
+ \\
+ \\
+ \\
\pm\end{array}$ \\
\hline API $50 \mathrm{CH}$ & $\begin{array}{l}\text { Rhamnose assimilation } \\
\text { D-Lyxose assimilation } \\
\text { D-Tagatose assimilation } \\
\text { 2-Ketogluconate assimilation }\end{array}$ & $\begin{array}{l}+ \\
- \\
- \\
-\end{array}$ & $\begin{array}{l}- \\
\pm \\
\pm \\
+\end{array}$ \\
\hline BIOLOG GN & $\begin{array}{l}\text { L-Fucose assimilation } \\
\text { L-Rhamnose assimilation } \\
\alpha \text {-Ketobutyrate assimilation } \\
\text { L-Serine assimilation } \\
\text { L-Threonine assimilation } \\
\text { Urocanic acid assimilation } \\
\text { D/L- } \alpha \text {-Glycerol phosphate assimilation }\end{array}$ & $\begin{array}{l}+ \\
+ \\
- \\
+ \\
- \\
- \\
+\end{array}$ & $\begin{array}{l}- \\
- \\
+ \\
- \\
+ \\
+ \\
-\end{array}$ \\
\hline API ZYM† & $\begin{array}{l}\text { Naphthol-AS-BI-phosphohydrolase } \\
\alpha \text {-Galactosidase } \\
\beta \text {-Galactosidase } \\
\alpha \text {-Fucosidase }\end{array}$ & $\begin{array}{l}+++ \\
+++ \\
\quad+ \\
+++\end{array}$ & $\begin{array}{c}+ \\
+ \\
++ \\
+ \\
+\end{array}$ \\
\hline Starch hydrolysis & $\begin{array}{l}\text { Starch agar } \\
\text { Starch Phytagel }\end{array}$ & $\begin{array}{l}+ \\
+\end{array}$ & $\begin{array}{l}- \\
\pm\end{array}$ \\
\hline Galactan hydrolysis & $\begin{array}{l}\text { Agars } \\
\kappa \text {-Carrageenan } \\
l \text {-Carrageenan }\end{array}$ & $\begin{array}{l}+++ \\
+++ \\
+++\end{array}$ & $\begin{array}{l}++ \\
\quad+ \\
\quad+\end{array}$ \\
\hline DNA hydrolysis & & + & + \\
\hline Cellulose hydrolysis & $\begin{array}{l}\text { Cellulose paper } \\
\text { CM-cellulose }\end{array}$ & $\begin{array}{l}- \\
-\end{array}$ & - \\
\hline
\end{tabular}

* PNPG, $p$-nitrophenyl- $\beta$-D-galactoside.

$\dagger$ The symbol + refers to $5 \mathrm{nmol}$ hydrolysed substrate and the symbol +++ to $>40 \mathrm{nmol}$ hydrolysed substrate in the API ZYM reading scale.

\section{DNA base composition}

The Chargaff's coefficient of the DNA of strain Dsij ${ }^{\mathrm{T}}$, as determined by the spectroscopic method (Ulitzur, 1972) and by the thermal denaturation method, were $44 \pm 1 \mathrm{~mol} \%(n=2)$ and $43 \pm 1 \mathrm{~mol} \%(n=2)$, respectively. The $\mathrm{G}+\mathrm{C}$ content of $[$ Cytophaga] uliginosa was $43 \pm 1 \mathrm{~mol} \%(n=2)$ by the thermal denaturation method (c.f. $42 \mathrm{~mol} \%$ determined by Reichenbach, 1989).

\section{$16 \mathrm{~S}$ rDNA sequence and phylogenetical analysis}

The 16S rDNA sequence of strain Dsij ${ }^{\mathrm{T}}$ was found to be closely related to [Cytophaga] uliginosa, with a sequence identity of $99.5 \%$, the two forming a distinct 


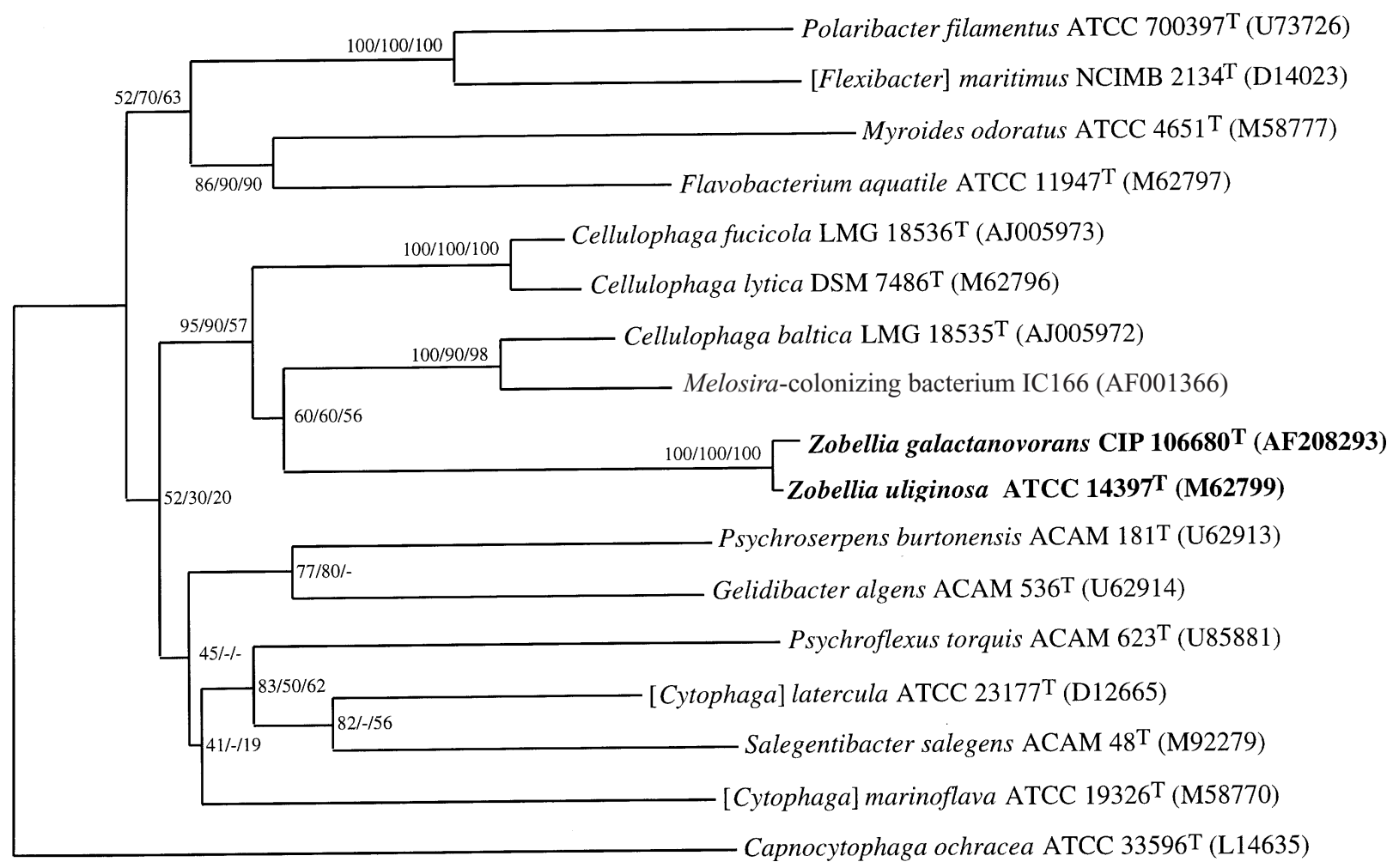

Fig. 4. Phylogenetic position of strain $\mathrm{Dsij}^{\top}$ amongst some marine representatives (except Capnocytophaga ochracea) of the family Flavobacteriaceae. Numbers after the strain names are culture collection numbers followed by GenBank accession numbers of $16 \mathrm{~S}$ rDNA sequences in parentheses. The topology shown is the tree obtained using the neighbourjoining method (Jukes and Cantor distance correction). Numbers at the nodes refer to the bootstrap values (100 replicates) in distance, maximum-likelihood and maximum-parsimony analyses, respectively, while dashes instead of numbers indicate that the node was not observed in the corresponding analysis. The scale bar represents the expected number of changes per sequence position.

deep branch (Fig. 4) in the family Flavobacteriaceae (Bernardet et al., 1996). The other sequences in the same clade were those of Cellulophaga baltica, Cellulophaga fucicola, the Melosira-colonizing bacterium IC166 and Cellulophaga lytica (Johansen et al., 1999). They displayed $91.5,91 \cdot 3,91 \cdot 3$ and $90.3 \%$ sequence identity, respectively, with the 16S rDNA sequence of strain Dsij ${ }^{\mathrm{T}}$. Phylogenetic trees generated using distance matrix, maximum-likelihood or parsimony analyses were similar, excepting the branches with low bootstrap values or with low probabilities in the maximum-likelihood analysis (Fig. 4).

\section{Fatty acid profile}

Strain Dsij ${ }^{\mathrm{T}}$, [Cytophaga] uliginosa and the related species Cellulophaga baltica, Cellulophaga lytica and Cellulophag a fucicola exhibited similar whole-cell fatty acid profiles (Table 2), featuring three major fatty acids, 15:0 iso, 17:0 iso $3-\mathrm{OH}$ and a mixture of $16: 1$ $\omega 7 c$ and 15:0 iso 2-OH (referred to as summed feature 3 in Table 2).

\section{DNA-DNA homology}

The DNA-DNA reassociation level, as determined by slot-blot hybridization, was $46 \%$ using the DNA from $\mathrm{Dsij}^{\mathrm{T}}$ as a probe against the DNA of [Cytophaga] uliginosa and $47 \%$ when the DNA from [Cytophaga] uliginosa was probed against Dsij ${ }^{\mathrm{T}}$ DNA. The reassociation level, determined by the renaturation method, was $50 \%$. These values are below the homology observed at the species level (Stackebrandt \& Goebel, 1994).

\section{Protein profiles}

PAGE revealed significant differences between the protein pattern of strain Dsij ${ }^{\mathrm{T}}$ and that of [Cytophaga] uliginosa (Fig. 5). In particular, strain Dsij ${ }^{\mathrm{T}}$ synthesized proteins which are not present in [Cytophaga] uliginosa, such as two peptides around $97 \mathrm{kDa}$ and another one with a molecular mass of approximately $66 \mathrm{kDa}$. Conversely, [Cytophaga] uliginosa produced proteins that were not present in strain $\mathrm{Dsij}{ }^{\mathrm{T}}$, around $100 \mathrm{kDa}$ and $110 \mathrm{kDa}$, and below $97 \mathrm{kDa}$. 
Table 2. Whole-cell fatty acid profiles (percentage composition) of strain Dsij', [Cytophaga] uliginosa and species of the Cellulophaga genus

\begin{tabular}{|c|c|c|c|c|c|c|c|c|c|c|}
\hline \multirow[t]{2}{*}{ Fatty acids } & \multicolumn{2}{|c|}{ Dsij $^{\mathrm{T}}$} & \multicolumn{2}{|c|}{$\begin{array}{l}\text { [Cytophaga }] \\
\text { uliginosa }\end{array}$} & \multicolumn{2}{|c|}{$\begin{array}{l}\text { Cellulophaga } \\
\text { lytica }\end{array}$} & \multicolumn{2}{|c|}{$\begin{array}{l}\text { Cellulophaga } \\
\text { fucicola }\end{array}$} & \multicolumn{2}{|c|}{$\begin{array}{c}\text { Cellulophaga } \\
\text { baltica }\end{array}$} \\
\hline & $\begin{array}{c}\text { Marine } \\
\text { agar }\end{array}$ & $\begin{array}{c}\text { GYM } \\
\text { agar }\end{array}$ & $\begin{array}{c}\text { Marine } \\
\text { agar }\end{array}$ & $\begin{array}{c}\text { GYM } \\
\text { agar }\end{array}$ & $\begin{array}{c}\text { Marine } \\
\text { agar }\end{array}$ & $\begin{array}{c}\text { GYM } \\
\text { agar }\end{array}$ & $\begin{array}{c}\text { Marine } \\
\text { agar }\end{array}$ & $\begin{array}{c}\text { GYM } \\
\text { agar }\end{array}$ & $\begin{array}{l}\text { Marine } \\
\text { agar }\end{array}$ & $\begin{array}{c}\text { GYM } \\
\text { agar }\end{array}$ \\
\hline $13: 0$ anteiso & & & & & & & & 1.00 & & \\
\hline $13: 1$ AT $12-13$ & 1.26 & $0 \cdot 854$ & & $2 \cdot 83$ & $1 \cdot 23$ & & & & & \\
\hline $14: 0$ iso & & & & & & & & 1.97 & & \\
\hline $14: 0$ & & $0 \cdot 98$ & & $1 \cdot 32$ & $0 \cdot 84$ & $3 \cdot 09$ & 1.00 & $2 \cdot 54$ & & $2 \cdot 57$ \\
\hline $15: 1$ iso $G$ & $8 \cdot 49$ & $10 \cdot 86$ & $8 \cdot 68$ & $7 \cdot 48$ & $11 \cdot 64$ & $4 \cdot 13$ & $10 \cdot 46$ & $5 \cdot 40$ & $6 \cdot 22$ & 4.91 \\
\hline $15: 1$ anteiso $\mathrm{A}$ & & $1 \cdot 27$ & & & & & & & & \\
\hline $15: 0$ iso & $23 \cdot 27$ & $18 \cdot 44$ & $38 \cdot 21$ & $24 \cdot 40$ & $20 \cdot 77$ & $21 \cdot 38$ & 23.64 & $18 \cdot 30$ & 11.02 & $9 \cdot 59$ \\
\hline $15: 0$ anteiso & $4 \cdot 25$ & $9 \cdot 30$ & & $7 \cdot 53$ & 4.91 & $9 \cdot 59$ & $3 \cdot 07$ & $17 \cdot 36$ & & $8 \cdot 76$ \\
\hline $15: 1 \omega 6 c$ & $1 \cdot 54$ & 1.73 & & & & & $2 \cdot 60$ & & $1 \cdot 00$ & \\
\hline $15: 0$ & $7 \cdot 33$ & $6 \cdot 06$ & $10 \cdot 35$ & 8.60 & $5 \cdot 01$ & $2 \cdot 59$ & $9 \cdot 16$ & $3 \cdot 32$ & $9 \cdot 23$ & $6 \cdot 74$ \\
\hline $16: 1$ iso $H$ & & & & & & & & 0.79 & & $3 \cdot 11$ \\
\hline $16: 0$ iso & & $1 \cdot 26$ & & & & & & 0.92 & & $5 \cdot 10$ \\
\hline Summed feature $3^{*}$ & $11 \cdot 06$ & $13 \cdot 07$ & 9.79 & 11.05 & $4 \cdot 28$ & $7 \cdot 19$ & $8 \cdot 18$ & $13 \cdot 01$ & $14 \cdot 37$ & $20 \cdot 00$ \\
\hline $16: 0$ & $2 \cdot 31$ & $4 \cdot 00$ & $3 \cdot 74$ & $7 \cdot 15$ & 1.92 & $8 \cdot 18$ & & 2.58 & $5 \cdot 96$ & $4 \cdot 02$ \\
\hline $15: 0$ iso $3-\mathrm{OH}$ & $5 \cdot 52$ & $5 \cdot 43$ & $5 \cdot 61$ & $3 \cdot 12$ & $11 \cdot 39$ & $10 \cdot 27$ & $14 \cdot 67$ & $10 \cdot 19$ & $4 \cdot 87$ & 5.54 \\
\hline $15: 02-\mathrm{OH}$ & & & & & $1 \cdot 15$ & & & $0 \cdot 81$ & & $1 \cdot 25$ \\
\hline $17: 1$ iso $\omega 9 c$ & $7 \cdot 60$ & $3 \cdot 15$ & $4 \cdot 42$ & $2 \cdot 34$ & $2 \cdot 26$ & & $1 \cdot 84$ & $1 \cdot 34$ & & 1.83 \\
\hline Summed feature $4 \dagger$ & $1 \cdot 36$ & & & & & & & & & \\
\hline $15: 03-\mathrm{OH}$ & & & & & $1 \cdot 14$ & & $2 \cdot 31$ & & 0.72 & \\
\hline $17: 1 \omega 8 c$ & & & & & & & & & $0 \cdot 97$ & \\
\hline $17: 1 \omega 6 c$ & $1 \cdot 00$ & 1.06 & & & & & & & & \\
\hline $16: 12-\mathrm{OH}$ & & & & & & & & & & $2 \cdot 40$ \\
\hline $16: 0$ iso $3-\mathrm{OH}$ & & $1 \cdot 10$ & & & 6.54 & 6.87 & $2 \cdot 70$ & $5 \cdot 21$ & $3 \cdot 45$ & 8.72 \\
\hline $16: 03-\mathrm{OH}$ & $1 \cdot 55$ & $1 \cdot 64$ & $3 \cdot 11$ & $4 \cdot 63$ & 3.02 & $6 \cdot 16$ & $1 \cdot 51$ & $4 \cdot 50$ & $2 \cdot 21$ & $5 \cdot 59$ \\
\hline $18: 1 \omega 5 c$ & & & & & & & 1.48 & 0.53 & & \\
\hline $17: 0$ iso $3-\mathrm{OH}$ & $14 \cdot 86$ & 11.92 & $16 \cdot 08$ & $11 \cdot 21$ & $15 \cdot 56$ & $16 \cdot 10$ & $10 \cdot 10$ & $8 \cdot 21$ & $9 \cdot 67$ & $7 \cdot 80$ \\
\hline $17: 02-\mathrm{OH}$ & & $2 \cdot 28$ & & $1 \cdot 88$ & $1 \cdot 10$ & & & $1 \cdot 43$ & & 2.08 \\
\hline
\end{tabular}

* The fatty acids 16:0 $\omega 7 c$ and 15:0 iso 2-OH could not be separated from each other by GC and together were considered summed feature 3 .

$\dagger$ The fatty acids 17:1 anteiso B and iso I could not be separated from each other by GC and together were considered summed feature 4.

\section{DISCUSSION}

The isolate Dsij ${ }^{\mathrm{T}}$ is a Gram-negative, gliding, strictly aerobic marine bacterium capable of cleaving the red algal galactans known as agars and carrageenans. It exhibits optimal growth at $35^{\circ} \mathrm{C}, 25 \mathrm{~g} \mathrm{NaCl}{ }^{-1}$ and $\mathrm{pH} 7 \cdot 0$, with a doubling time of $50 \mathrm{~min}$. On ZoBell agar strain Dsij $^{\mathrm{T}}$ forms spreading, yellow-orange colonies.

Analysis of 16S rDNA sequences indicates that strain Dsij ${ }^{\mathrm{T}}$ belongs to the order Cytophagales (CFB group or rRNA superfamily V) and to the family Flavobacteriaceae (Bernardet et al., 1996). The $\mathrm{G}+\mathrm{C}$ content of genomic DNA for strain Dsij ${ }^{\mathrm{T}}$ is $43 \mathrm{~mol} \%$, within the range of this family (29-45 $\mathrm{mol} \%$; Bernardet et al., 1996). In the 16S rDNA tree, strain Dsij $^{T}$ and [Cytophaga] uliginosa form a clade with bootstrap values of $100 \%$. This close relationship between the two taxa was confirmed by the high score $(99.5 \%)$ of sequence identity between the $16 \mathrm{~S}$ rDNA genes of the two strains and by a high number of identical phenotypic characteristics (Table 1). Yet the differences in their total protein profiles, the low DNA-DNA hybridization values (below $50 \%$ ) and the phenotypic differences between strain $\mathrm{Dsij}^{\mathrm{T}}$ and [Cytophaga] uliginosa (Table 1) indicate that they should be recognized as two distinct species.

Although the 16S rDNA tree indicates that the Dsij ${ }^{\mathrm{T}} /[$ Cytophaga $]$ uliginosa branch emerges from within the clade constituted by Cellulophaga and the Melosira-colonizing bacterium, the bootstrap values of this node are $60 \%$ or less, indicating that the position of this branching is unclear. Moreover, the $\mathrm{Dsij}^{\mathrm{T}} /[$ Cytophaga] uliginosa branch is long, showing that these two species have had a long or rapid, yet independent, evolution. Finally, the highest sequence 


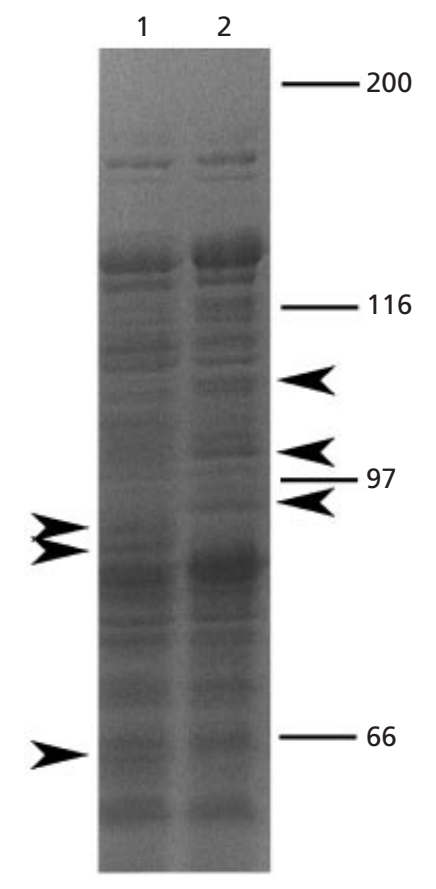

Fig. 5. SDS-PAGE of protein extracts from strain $\mathrm{Dsij}^{\top}$ (lane 1) and [Cytophaga] uliginosa (lane 2). Protein bands were visualized by Coomassie blue staining. Arrows indicate the main differences between the two lanes. Molecular masses are indicated on the right in $\mathrm{kDa}$.

identity between this branch and the genus Cellulophaga (91.8\%, between [Cytophaga] uliginosa and Cellulophaga baltica) is in the same range as those observed between the genera of the Flavobacteriaceae $(90 \cdot 5-92 \cdot 3 \%)$. Altogether, the phylogenetic relationships of the Flavobacteriaceae suggest that the [Cytophaga] uliginosa/Dsij ${ }^{\mathrm{T}}$ clade and Cellulophaga constitute two distinct genera. It is also noteworthy here that both the solidity of the phylogenetic position of the Melosira-colonizing bacterium IC166 and its high rDNA 16S sequence identity with Cellulophaga baltica, $96 \cdot 2 \%$, suggest that this strain is related to the genus Cellulophaga.

Strain Dsij ${ }^{\mathrm{T}}$, [Cytophaga] uliginosa and Cellulophaga species all synthesize 2- and 3-hydroxylated iso/ anteiso-branched fatty acids, with chains of 15 and 17 carbon atoms (Table 2). This combination of fatty acids is characteristic of members of the Cytophaga/Flavobacterium complex. In the dendrograms inferred from these analyses, however, species clustering depended on the culture medium (data not shown), indicating that fatty acid composition is not stringent enough to discriminate the above bacteria at the genus level. In particular, Cellulophaga baltica markedly differed from the other Cellulophaga species by its low content of 15:0 iso 3-OH (Table 2).

Degradation of soluble cellulose, in the form of AZCLhydroxyethylcellulose, was described as a character- istic of the genus Cellulophaga (Johansen et al., 1999). In our hands, Cellulophaga baltica, Cellulophaga lytica and Cellulophag a fucicola did hydrolyse CM-cellulose, whereas Dsij ${ }^{\mathrm{T}}$ and [Cytophaga] uliginosa did not. These two strains and, more surprisingly, the three Cellulophaga species, did not degrade crystalline cellulose. As already observed by Johansen et al. (1999), other phenotypic characteristics, such as colony colour, the presence or absence of flexirubin and the $\mathrm{G}+\mathrm{C}$ content of genomic DNA, as well as the maximum growth temperature separate [Cytophaga] uliginosa and Dsij ${ }^{\mathrm{T}}$ from the genus Cellulophaga. [Cytophaga] uliginosa and $\mathrm{Dsij}^{\mathrm{T}}$ are both characterized by orange colonies, a maximum growth temperature of $42{ }^{\circ} \mathrm{C}$, the presence of flexirubin and by $\mathrm{G}+\mathrm{C}$ values above $40 \mathrm{~mol} \%$ (Table 3), whereas Cellulophaga species consist of yellow colonies, cannot grow above $40{ }^{\circ} \mathrm{C}$, do not synthesize flexirubin and exhibit a Chargaff's coefficient below $33 \mathrm{~mol} \%$ (Johansen et al., 1999). These two latter features are included in the description of the genus Cellulophaga (Johansen et al., 1999).

In conclusion, based on both the above phenotypic and phylogenetic data, we propose that the strain Dsij ${ }^{\mathrm{T}}$ and [Cytophaga] uliginosa form a novel taxonomic group, equivalent to a new genus, Zobellia gen. nov., within the family Flavobacteriaceae, and containing two species, Zobellia galactanovorans gen. nov., sp. nov. and Zobellia uliginosa gen. nov., comb. nov. Although the genera Flavobacterium and Chryseobacterium are not closely related to Zobellia uliginosa and Zobellia galactanovorans, they also consist of yellow bacteria containing flexirubin, but they are distinguished by a low Chargaff's coefficient. Moreover, the genus Flavobacterium is composed of nonmarine bacteria (Bernardet et al., 1996) while the genus Chryseobacterium is characterized by the absence of gliding motility. Table 3 presents the phenotypic characteristics which distinguish these two species from the other genera of the family Flavobacteriaceae.

\section{Description of Zobellia gen. nov.}

Zobellia (Zo.bel.li.a. N.L. fem. n. Zobellia in honour of C. E. ZoBell, who has isolated and characterized numerous marine bacteria, notably [Cytophaga] uliginosa in 1944, and for his general contribution to the taxonomy of marine bacteria).

Marine bacteria with Gram-negative cells consisting of non-spore-forming rods $(0 \cdot 2$ by $1 \cdot 5-8 \cdot 0 \mu \mathrm{m})$. Colonies are yellow or orange and possess a flexirubin-type pigment. Cells do not possess flagella but exhibit a gliding motility, are chemo-organotrophic and heterotrophic. Metabolism is respiratory, not fermentative and strictly aerobic, with oxygen as electron acceptor. Nitrate is reduced to nitrite. Cells hydrolyse the galactans from red seaweeds such as agar, $\kappa$ carrageenan and $l$-carrageenan. Do not hydrolyse crystalline or amorphous cellulose. Produce acid from many carbohydrates. The genus belongs to the family 
Table 3. Phenotypic characteristics differentiating Zobellia species from other member of the family Flavobacteriaceae

1, Zobellia galactanovorans; 2, Zobellia uliginosa; 3, genus Cellulophaga; 4, [Cytophaga] marinoflava; 5, Gelidibacter algens; 6, Psychroserpens burtonensis; 7, Salegentibacter salegens; 8, [Cytophaga] latercula; 9, genus Psychroflexus; 10, genus Polaribacter; 11, [Flexibacter] maritimus group (includes [Flexibacter] maritimus and [Flexibacter] ovolyticus); 12, genus Flavobacterium; 13, genus Chryseobacterium. - , Negative; +, positive; v, variable; O, orange; Y, yellow; R, red. Data from Wakabayashi et al. (1986); Reichenbach (1989); Hansen et al. (1992); Dobson et al. (1993); Vandamme et al. (1994); Bernardet et al. (1996); Bowman et al. (1997, 1998); Gosink et al. (1998); Johansen et al. (1999); McCammon \& Bowman (2000); and this study.

\begin{tabular}{|c|c|c|c|c|c|c|c|c|c|c|c|c|c|}
\hline Characteristic & 1 & 2 & 3 & 4 & 5 & 6 & 7 & 8 & 9 & 10 & 11 & 12 & 13 \\
\hline Gliding motility & + & + & + & + & + & - & - & - & $\mathrm{V}$ & - & + & $+^{*}$ & - \\
\hline Pigment & $\mathrm{Y}-\mathrm{O}$ & $\mathrm{O}$ & $\mathrm{Y}$ & $\mathrm{Y}$ & $\mathrm{Y}$ & $\mathrm{Y}$ & $\mathrm{Y}$ & $\mathrm{O}-\mathrm{R}$ & $\mathrm{O}$ & $\mathrm{O}$ & $\mathrm{Y}-\mathrm{O}$ & $\mathrm{Y}$ & $\mathrm{Y} \dagger$ \\
\hline Presence of flexirubin & + & + & - & - & - & - & - & - & - & - & - & $\mathrm{V}$ & + \\
\hline Growth at $25^{\circ} \mathrm{C}$ & + & + & + & + & - & - & + & + & $\mathrm{V}$ & - & + & + & + \\
\hline Seawater requirement & + & + & + & - & + & + & - & + & $\mathrm{V}$ & + & + & $-t$ & $\mathrm{~V}$ \\
\hline Carbohydrate utilization & + & + & + & + & + & - & + & + & + & + & - & + & + \\
\hline Catalase & + & + & + & + & + & + & + & - & $\mathrm{V}$ & + & + & + & + \\
\hline Oxidase & + & + & $-\S$ & + & - & - & + & + & + & $\mathrm{V}$ & + & $+\|$ & + \\
\hline \multicolumn{14}{|l|}{ Hydrolysis of: } \\
\hline Gelatin & + & + & $\mathrm{V}$ & NA & $\mathrm{V}$ & $\mathrm{V}$ & + & + & $-\boldsymbol{\top}$ & $\mathrm{V}$ & + & $+\#$ & + \\
\hline Aesculin & + & + & NA & + & + & - & + & NA & $\mathrm{V}$ & $\mathrm{V}$ & $-* *$ & $\mathrm{~V}$ & + \\
\hline Starch & + & - & + & + & + & - & + & - & + & + & - & $\mathrm{V}$ & $\mathrm{V}$ \\
\hline Agar & + & + & + & - & - & - & - & + & - & - & - & $-\dagger \dagger$ & - \\
\hline$\beta$-Galactosidase activity & + & + & NA & NA & - & $\mathrm{V}$ & + & + & - & $\mathrm{V}$ & - & $\mathrm{V}$ & $\mathrm{V}$ \\
\hline Nitrate reduction & + & + & - & + & - & - & + & - & - & - & + & $\mathrm{V}$ & $\mathrm{V}$ \\
\hline $\mathrm{G}+\mathrm{C}(\mathrm{mol} \%)$ & 43 & 42 & $32-33$ & 37 & $36-38$ & $27-29$ & $37-38$ & 32 & $32-36$ & $31-34$ & $29-32$ & $32-37$ & $33-38$ \\
\hline
\end{tabular}

NA, No information available.

* Gliding motility has not been observed in Flavobacterium branchiophilum.

$\uparrow$ Some Chryseobacterium meningosepticum strains are non-pigmented.

† Excepting Flavobacterium flevense.

$\S$ Excepting Cellulophaga lytica.

\| Excepting Flavobacterium saccharophilum.

- Some Psychroflexus gondwanensis strains can hydrolyse gelatin.

\# Excepting some Flavobacterium aquatile strains and Flavobacterium flevense.

** Only reported for [Flexibacter] maritimus.

$\dagger \dagger$ Excepting Flavobacterium flevense and Flavobacterium saccharophilum.

Flavobacteriaceae. The $\mathrm{G}+\mathrm{C}$ content of the genomic DNA ranges from 42 to $44 \mathrm{~mol} \%$. The type species is Zobellia galactanovorans.

\section{Description of Zobellia galactanovorans sp. nov. (basonym 'Cytophaga drobachiensis' Barbeyron et al. 1998)}

Zobellia galactanovorans (ga.lac.ta.no.vo'rans. M.L. n. galactan polygalactose; L. v. vorare to devour; M.L. fem. adj. galactanovorans galactan-devouring).

Colonies on ZoBell 2216E agar plate are yellow and spread rapidly on the surface of the plate. Cells are rods $(0.3-0.4$ by $3.0-8.0 \mu \mathrm{m})$, with rounded ends and are non-motile in liquid phase. On solid surfaces, gliding motility is easily observed. Cells hydrolyse agar and $\kappa$-carrageenan. $l$-Carrageenan is liquefied within 1 week at room temperature. Gelatin and DNA are also hydrolysed. Starch is hydrolysed in starch agar and starch Phytagel plates. Cells are positive for catalase, cytochrome- $c$ oxidase, $\beta$-glucosidase (aesculin test) and $\beta$-galactosidase activities ( $o$ - and $p$-nitrophenyl- $\beta$ D-galactoside tests). Cells do not produce $\mathrm{H}_{2} \mathrm{~S}$ nor indole from tryptophan. The Voges-Proskauer reaction is negative. Do not possess urease or arginine dihydrolase. D-Glucose, L-arabinose, D-mannose, Dmannitol, L-rhamnose, L-fucose, maltose, $\mathrm{N}$-acetylglucosamine, D/L-glycerol phosphate or L-serine can serve as the sole carbon source, but not D-lyxose, Dtagatose, $\alpha$-ketobutyric acid, L-threonine, urocanic acid, gluconate, 2-keto-gluconate, caprate, adipate, malate, citrate or phenyl acetate. Acid production is observed from D-glucose, sucrose, maltose, L-arabinose, rhamnose, D-fructose, D-galactose, D-mannose, D-mannitol and starch, but not from D-sorbitol or glycerol. The DNA $\mathrm{G}+\mathrm{C}$ content is $43 \mathrm{~mol} \%$. The type strain is Zobellia galactanovorans Dsij ${ }^{\mathrm{T}}$, isolated 
from pieces of the red alga Delesseria sanguinea (Huds.) Lamour. Strain Dsij ${ }^{\mathrm{T}}$ has been deposited in the DSMZ and in the Institut Pasteur Collection under the accession numbers DSM $12802^{\mathrm{T}}$ and CIP $106680^{\mathrm{T}}$, respectively.

\section{Description of Zobellia uliginosa comb. nov. (basonym Flavobacterium uliginosum ZoBell and Upham 1944)}

Other synonyms: Agarbacterium uliginosum (ZoBell and Upham 1944) Breed 1957; Cytophaga uliginosa (ZoBell and Upham 1944) Reichenbach 1989.

Description was previously given for [Cytophaga] uliginosa (Reichenbach, 1989). In addition, the following features are observed. In contrast to Zobellia galactanovorans, colonies on ZoBell 2216E solidified with agar are orange with a very tenacious slime, without or with weak spreading activity. Moreover, the gliding motility, although easily observed, is characterized by the observation that cells do not move away from the colony. Cells do not possess an arginine dihydrolase, but feature $\beta$-glucosidase (aesculin test) and $\beta$-galactosidase ( $p$-nitrophenyl galactoside test) activities. Cells hydrolyse DNA, gelatin and chitin. Starch activity is not detected on starch agar plates, but a weak activity is detected on starch Phytagel plates. Hydrolysis of $\kappa$-carrageenan and $l$-carrageenan is weaker than in Zobellia galactanovorans, whereas both species hydrolyse agar at similar rates. D-Glucose, arabinose, D-mannose, D-mannitol, $N$-acetylglucosamine, gluconate, 2-keto-gluconate, $\alpha$ ketobutyric acid, L-threonine or urocanic acid can serve as the sole carbon source, but not L-rhamnose, Lfucose, L-serine or D/L-glycerol phosphate. Acid production occurs in the presence of D-glucose, sucrose or maltose, but not in the presence of D-mannitol or glycerol.

Tables $1-3$ and 2 show features that discriminate the two Zobellia species and distinguish the genus Zobellia from the other members of the Flavobacteriaceae.

\section{NOTE ADDED IN PROOF}

Recently, Bowman (2000) proposed that [Cytophaga] uliginosa be included in the genus Cellulophaga. However, as discussed above, the $\mathrm{G}+\mathrm{C}$ content, maximum growth temperature, presence of flexirubin and utilization of CM-cellulose, together with the important phylogenetic distance between the genera Cellulophaga and Zobellia indicate that, in our opinion, Bowman's proposition would result in too heterogenous a Cellulophaga genus.

\section{ACKNOWLEDGEMENTS}

The excellent technical assistance of Catherine Charpentier and the help of the DMSZ are gratefully acknowledged. The authors also thank Christian Jeanthon and Jean-François
Bernardet for their helpful suggestions and encouragement during the course of this work.

\section{REFERENCES}

Aoki, T., Araki, T. \& Kitamikado, M. (1990). Purification and characterization of a novel beta-agarase from Vibrio sp. AP-2. Eur J Biochem 187, 461-465.

Araki, C. \& Arai, K. (1956). Studies on the chemical constitution of agar-agar. XVIII. Isolation of a new crystalline disaccharide by enzymatic hydrolysis of agar-agar. Bull Chem Soc Jpn 29, 339-345.

Araki, C. \& Arai, K. (1957). Studies on the chemical constitution of agar-agar. XX. Isolation of a tetrasaccharide by enzymatic hydrolysis of agar-agar. Bull Chem Soc Jpn 30, 287-293.

Barbeyron, T. (1993). Caractérisation moléculaire d'une sulfatase, d'une kappa-carraghénase et d'une iota-carraghénase chez deux bactéries marines Alteromonas carrageenovora et Cytophaga drobachiensis. Doctorat thesis, Pierre and Marie Curie-Paris VI University.

Barbeyron, T., Kean, C. \& Forterre, P. (1984). DNA adenine methylation of GATC sequences appeared recently in the Escherichia coli lineage. J Bacteriol 160, 586-590.

Barbeyron, T., Gérard, A., Potin, P., Henrissat, B. \& Kloareg, B. (1998). The kappa-carrageenase of the marine bacterium Cytophaga drobachiensis: structural and phylogenetic relationships within family-16 glycoside hydrolases. Mol Biol Evol 15, 528-537.

Barbeyron, T., Michel, G., Potin, P., Henrissat, B. \& Kloareg, B. (2000). Iota-carrageenases constitute a novel family of glycoside hydrolases, unrelated to that of kappa-carrageenases. $J$ Biol Chem 275, 35499-35505.

Benson, D. A., Boguski, M. S., Lipman, D. J., Ostell, J., Ouellette, B. F., Rapp, B. A. \& Wheeler, D. L. (1999). GenBank. Nucleic Acids Res 27, 12-17.

Bernardet, J.-F., Segers, P., Vancanneyt, M., Berthe, F., Kersters, K. \& Vandamme, P. (1996). Cutting a gordian knot: emended classification and description of the genus Flavobacterium, emended description of the family Flavobacteriaceae, and proposal of Flavobacterium hydatis nom. nov. (basonym, Cytophaga aquatilis Strohl and Tait 1978). Int J Syst Bacteriol 46, 128-148.

Bibb, M. J., Jones, G. H., Joseph, R., Buttner, M. J. \& Ward, J. M. (1987). The agarase gene $(\operatorname{dag} A)$ of Streptomyces coelicolor A3(2): affinity purification and characterization of the cloned gene product. J Gen Microbiol 133, 2089-2096.

Bowman, J. P., McCammon, S. A., Brown, J. L., Nichols, P. D. \& McMeekin, T. A. (1997). Psychroserpens burtonensis gen. nov., sp. nov., and Gelidibacter algens gen. nov., sp. nov., psychrophilic bacteria isolated from Antartica lacustrine and sea habitats. Int J Syst Bacteriol 47, 670-677.

Bowman, J. P., McCammon, S. A., Lewis, T., Skerratt, J. H., Brown, J. L., Nichols, D. S. \& McMeekin, T. A. (1998). Psychroflexus torquis gen. nov., sp. nov., a psychrophilic species from Antartica sea ice, and reclassification of Flavobacterium gondwanense (Dobson et al. 1993) as Psychroflexus gondwanense gen. nov., comb. nov. Microbiology 144, 1601-1609.

Conn, H. J., Bartholomew, J. W. \& Jennison, M. W. (1957). Staining methods. In Manual of Microbial Methods, pp. 30-36. Edited by the Society of American Bacteriologists. New York: McGraw-Hill.

Craigie, J. S. (1990). Cell walls. In Biology of the Red Algae, pp. 
221-257. Edited by K. M. Cole \& R. G. Sheath. Cambridge: Cambridge University Press.

De Ley, J., Cattoir, H. \& Reynaerts, A. (1970). The quantitative measurement of DNA hybridization from renaturation rates. Eur J Biochem 12, 133-142.

De Ruiter, G. A. \& Rudolph, B. (1997). Carrageenan biotechnology. Trends Food Sci Technol 8, 389-395.

Dobson, S. J., Colwell, R. R., McMeekin, T. A. \& Franzmann, P. D. (1993). Direct sequencing of the polymerase chain reactionamplified 16S rRNA gene of Flavobacterium gondwanense sp. nov. and Flavobacterium salegens sp. nov., two new species from a hypersaline Antartic lake. Int J Syst Bacteriol 43, 77-83.

Doudoroff, M. \& Palleroni, N. J. (1974). Genus I. Pseudomonas Migula 1894. In Bergey's Manual of Determinative Bacteriology, pp. 217-243. Edited by R. E. Buchanan \& N. E. Gibbons. Baltimore: Williams \& Wilkins.

Duckworth, M. \& Turvey, J. R. (1969). An extracellular agarase from a Cytophaga species. Biochem J 113, 139-142.

Dungan, C. F., Elston, R. A. \& Schiewe, M. H. (1989). Evidence for colonization of hinge ligaments in cultured juvenile Pacific Oysters (Crassostrea gigas) by cytophaga-like bacteria. Appl Environ Microbiol 55, 1128-1135.

Felsenstein, J. (1981). Evolutionary trees from DNA sequences: a maximum likelihood approach. J Mol Evol 17, 368-376.

Felsenstein, J. (1985). Confidence limits on phylogenies: an approach using the bootstrap. Evolution 39, 783-791.

Fitch, W. M. (1971). Toward defining the course of evolution: minimum change for a specific tree topology. Syst Zool 20, 406-416.

Flament, D. (1999). Etude fonctionelle et structurale des galactane hydrolases. Doctorat thesis, Rennes I University.

Gosink, J. J., Woese, C. R. \& Staley, J. T. (1998). Polaribacter gen. nov., with three new species, $P$. irgensii sp. nov., $P$. franzmanii sp. nov. and $P$. filamentus sp. nov., gas vacuolate polar marine bacteria of the Cytophaga-Flavobacterium-Bacteroides group and reclassification of "Flectobacillus glomeratus" as Polaribacter glomeratus comb. nov. Int J Syst Bacteriol 48, 223-235.

Gran, H. H. (1902). Studien über meerebakterien. II. über die hydrolyse des agar-agars durch ein neues enzym, die gelase. Bergens Museums Aarborg 2, 1-16.

Greer, C. W. \& Yaphe, W. (1984). Purification and properties of iota-carrageenase from a marine bacterium. Can J Microbiol 30, 1500-1506.

Groleau, D. \& Yaphe, W. (1977). Enzymatic hydrolysis of agar: purification and characterization of $\beta$-neoagarotetraose hydrolase from Pseudomonas atlantica. Can J Microbiol 23, 672-679.

Hansen, G. H., Bergh, Ø., Michaelsen, J. \& Knappskog, D. (1992). Flexibacter ovolyticus sp. nov., a pathogen of eggs and larvae of atlantic halibut, Hippoglossus hippoglossus L. Int J Syst Bacteriol 42, 451-458.

Hicks, R. E, Amann, R. I. \& Stahl, D. A. (1992). Dual staining of natural bacterioplankton with 4',6-diamidino-2-phenylindole and fluorescent oligonucleotide probes targeting kingdom-level 16S rRNA sequences. Appl Environ Microbiol 58, 2158-2163.

Hofsten, B. V. \& Malmqvist, M. (1975). Degradation of agar by a Gram-negative bacterium. J Gen Microbiol 87, 150-158.

Holmes, B., Owen, R. J. \& McMeekin, T. A. (1984). Genus Flavobacterium Bergey, Harrison, Breed, Hammer and Huntoon 1923. In Bergey's Manual of Systematic Bacteriology, vol. 1, pp. 353-360. Edited by N. R. Krieg \& J. G. Holt. Baltimore: Williams \& Wilkins.

Hugh, R. \& Leifson, E. (1953). The taxonomic significance of fermentative versus oxidative metabolism of carbohydrates by various gram-negative bacteria. J Bacteriol 66, 24-26.

Humm, H. J. (1946). Marine agar digesting bacteria of the South atlantic coast. Duke Univ Mar Sta Bull 3, 43-75.

Huss, V. A. R., Festl, H. \& Shleifer, K. H. (1983). Studies on the spectrophotometric determination of DNA hybridization from renaturation rates. Syst Appl Microbiol 4, 184-192.

Ivanova, T. L., Turova, T. P. \& Antonov, A. S. (1988). DNA-DNA hybridization studies on some purple non sulfur bacteria. Syst Appl Microbiol 10, 259-263.

Johansen, J. E., Nielsen, P. \& Sjoholm, C. (1999). Description of Cellulophaga baltica gen. nov., sp. nov. and Cellulophaga fucicola gen. nov., sp. nov. and reclassification of [Cytophaga] lytica to Cellulophaga lytica gen. nov., comb. nov. Int J Syst Bacteriol 49, 1231-1240.

Johnson, J. L. (1984). DNA reassociation and RNA hybridization of bacterial nucleic acids. In Bergey's Manual of Systematic Bacteriology, vol. 1, pp. 8-11. Edited by N. R. Krieg \& J. G. Holt. Baltimore: Williams \& Wilkins.

Jukes, T. H. \& Cantor, C. R. (1969). Evolution of protein molecules. In Mammalian Protein Metabolism, vol. 3, pp. 21-132. Edited by H. N. Munro. New York: Academic Press.

Kane, M. D, Poulsen, L. K. \& Stahl, D. A. (1993). Monitoring the enrichment and isolation of sulfate-reducing bacteria by using oligonucleotide hybridization probes designed from environmentally derived 16S rRNA sequences. Appl Environ Microbiol 59, 682-686.

Kidby, D. K. \& Davidson, D. J. (1973). A convenient ferricyanide estimation of reducing sugars in the nanomole range. Anal Biochem 55, 321-325.

Kristjánsson, J. K., Hjörleifsdóttir, S., Marteinsson, V.T. \& Alfredsson, G. A. (1994). Thermus scotoductus, sp. nov., a pigment-producing thermophilic bacterium from hot tap water in Iceland and including Thermus sp. X-1. Syst Appl Microbiol 17, 44-50.

Leadbetter, E. R., Holt, S. C. \& Socransky, S. S. (1979). Capnocytophaga: new genus of gram-negative gliding bacteria. I. General characteristics, taxonomic considerations and significance. Arch Microbiol 122, 9-16.

Leon, O., Quintana, L., Peruzzo, G. \& Slebe, J. C. (1992). Purification and properties of an extracellular agarase from Alteromonas sp. strain C-1. Appl Environ Microbiol 58, 4060-4063.

Ludwig, W. \& Strunk, O. (1997). ARB : a software environment for sequence data. http://www.mikro.biologie.tu-muenchen.de/ $\mathrm{pub} / \mathrm{ARB} /$ documentation/

McCammon, S. A. \& Bowman, J. P. (2000). Taxonomy of Antarctic Flavobacterium species: description of Flavobacterium gillisiae sp. nov., Flavobacterium tegetincula sp. nov. and Flavobacterium xanthum sp. nov., nom. rev. and reclassification of [Flavobacterium] salegens as Salegentibacter salegens gen. nov., comb. nov. Int J Syst Evol Microbiol 50, 1055-1063.

Maidak, B. L., Cole, J. R., Parker, C. T. Jr. \& 11 other authors. (1999). A new version of the RDP (Ribosomal Database Project). Nucleic Acids Res 27, 171-173.

Marmur, J. \& Doty, D. (1962). Determination of the base composition of deoxyribonucleic acid from its thermal denaturation temperature. J Mol Biol 5, 109-118. 
Morrice, L. M., Mclean, M. W., Williamson, F. B. \& Long, W. F. (1983). $\beta$-Agarases I and II from Pseudomonas atlantica. Purifications and some properties. Eur J Biochem 135, 553-558.

Nakagawa, Y. \& Yamasato, K. (1993). Phylogenetic diversity of the genus Cytophaga revealed by $16 \mathrm{~S}$ rRNA sequencing and menaquinone analysis. J Gen Microbiol 139, 1155-1161.

Nakagawa, Y. \& Yamasato, K. (1996). Emendation of the genus Cytophaga and transfer of Cytophaga agarovorans and Cytophaga salmonicolor to Marinilabilia gen. nov.: phylogenetic analysis of the Flavobacterium-Cytophaga complex. Int J Syst Bacteriol 46, 599-603.

Potin, P. (1992). Recherche, production, purification et caractérisation de galactane-hydrolases pour la préparation d'oligosaccharides des parois d'algues rouges. Doctorat thesis, Bretagne Occidentale University.

Potin, P., Sanséau, A., Le Gall, Y., Rochas, C. \& Kloareg, B. (1991). Purification and characterization of a new $\kappa$-carrageenase from a marine Cytophaga-like bacterium. Eur J Biochem 201, 241-247.

Potin, P., Richard, C., Rochas, C. \& Kloareg, B. (1993). Purification and characterization of the $\alpha$-agarase from Alteromonas agarlyticus (Cataldi) comb. nov., strain GJ1B. Eur J Biochem 214, 599-607.

Quatrano, R. S. \& Caldwell, J. (1978). Isolation of a unique bacterium capable of growth on a wide variety of polysaccharides from macroalgae. Appl Environ Microbiol 36, 979-981.

Rees, D. A. (1962). Some properties of the cell wall mucilage of marine algae. Brit Phycol Bull 2, 180-181.

Rees, D. A. (1969). Structure, conformation and mechanism in the formation of polysaccharide gels and networks. $A d v$ Carbohydr Biochem 24, 267-332.

Reichenbach, H. (1989). Genus I. Cytophaga Winogradsky 1929. In Bergey's Manual of Systematic Bacteriology, vol. 3, pp. 2015-2050. Edited by J. T. Staley, M. P. Bryant, N. Pfenning \& J. G. Holt. Baltimore: Williams \& Wilkins.

Reichenbach, H., Kleinig, H. \& Achenbach, H. (1974). The pigment of Flexibacter elegans: novel and chemosystematically useful coumpounds. Archiv Microbiol 101, 131-144.

Saitou, N. \& Nei, M. (1987). The neighbor-joining method: a new method for reconstructing phylogenetic trees. Mol Biol Evol 4, 406-425.
Sarwar, G., Sakata, T. \& Kakimoto, D. (1983). Isolation and characterization of carrageenan-decomposing bacteria from marine environment. J Gen Appl Microbiol 29, 145-155.

Smibert, R. M. \& Krieg, N. R. (1981). General characterization. In Manual of Methods for General Bacteriology, pp. 409-443. Edited by P. Gerhardt, R. G. E. Murray, R. N. Costilow, E. W. Nester, W. A. Wood, N. R. Krieg \& G. B. Phillips. Washington, DC: American Society for Microbiology.

Stackebrandt, E. \& Goebel, B. M. (1994). Taxonomic note: a place for DNA-DNA reassociation and 16S rRNA sequence analysis in the present species definition in bacteriology. Int $J$ Syst Bacteriol 44, 846-849.

Stanier, R. Y. (1941). Studies on marine agar-digesting bacteria. $J$ Bacteriol 42, 527-559.

Sugano, Y., Terada, I., Arita, M., Noma, M. \& Matsumoto, T. (1993). Purification and characterization of a new agarase from a marine bacterium, Vibrio sp. strain JT0107. Appl Environ Microbiol 59, 1549-1554.

Ulitzur, S. (1972). Rapid determination of DNA base composition by ultraviolet spectroscopy. Biochim Biophys Acta 272, $1-11$.

Vandamme, P., Bernardet, J.-F., Segers, P., Kersters, K. \& Holmes, B. (1994). New perpectives in the classification of the Flavobacteria: description of Chryseobacterium gen. nov., Bergeyella gen. nov. and Empedobacter nom. rev. Int J Syst Bacteriol 44, 827-831.

Vattuone, M. A., de Flores, E. A. \& Sampietro, A. R. (1975). Isolation of neoagarobiose and neoagarotetraose from agarose digested by Pseudomonas elongata. Carbohydr Res 39, 164-167.

Wakabayashi, H., Hikida, M. \& Masumura, K. (1986). Flexibacter maritimus sp. nov., a pathogen of marine fishes. Int $J$ Syst Bacteriol 36, 396-398.

Weigl, J. \& Yaphe, W. (1966). The enzymic hydrolysis of carrageenan by Pseudomonas carrageenovora: purification of a $\kappa$-carrageenase. Can J Microbiol 12, 939-947.

ZoBell, C. E. (1941). Studies on marine bacteria. I. The cultural requirements of heterotrophic aerobes, J Mar Res 4, 41-75.

ZoBell, C. E. \& Upham, H. C. (1944). A list of marine bacteria including descriptions of sixty new species. Bull Scripps Inst Oceanogr Univ Calif 5, 239-292. 